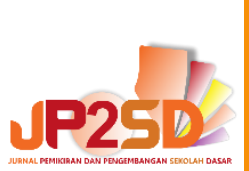

UNIVERSITAS MUHAMMADIYAH MALANG JP2SD (JURNAL PEMIKIRAN

DAN PENGEMBANGAN SEKOLAH DASAR)

http://ejournal.umm.ac.id/index.php/jp2sd

p-ISSN: 2338-1140 e-ISSN: 2527-3043

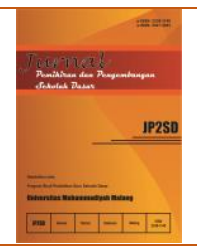

\title{
Strategi Pengembangan RPP Melalui Model Pembelajaran Project Based Learning
}

\author{
Sri Dadi ${ }^{a{ }^{*}}$, Nani Yuliantini ${ }^{\mathrm{b} 2}$, Panut Setiono ${ }^{\mathrm{c} 3}$ \\ ${ }^{a}$ Program Studi Pendidikan Guru Sekolah Dasar, FKIP, Universitas Bengkulu, Indonesia \\ ${ }^{\mathrm{b}}$ Program Studi Pendidikan Guru Sekolah Dasar, FKIP, Universitas Bengkulu, Indonesia \\ ${ }^{\mathrm{c}}$ Program Studi Pendidikan Guru Sekolah Dasar, FKIP, Universitas Bengkulu, Indonesia \\ 1srid3154@gmail.com, ${ }^{2}$ naniyuliantini@gmail.com, ${ }^{3}$ setiono.pgsd@unib.ac.id \\ * Penulis Korespondensi
}

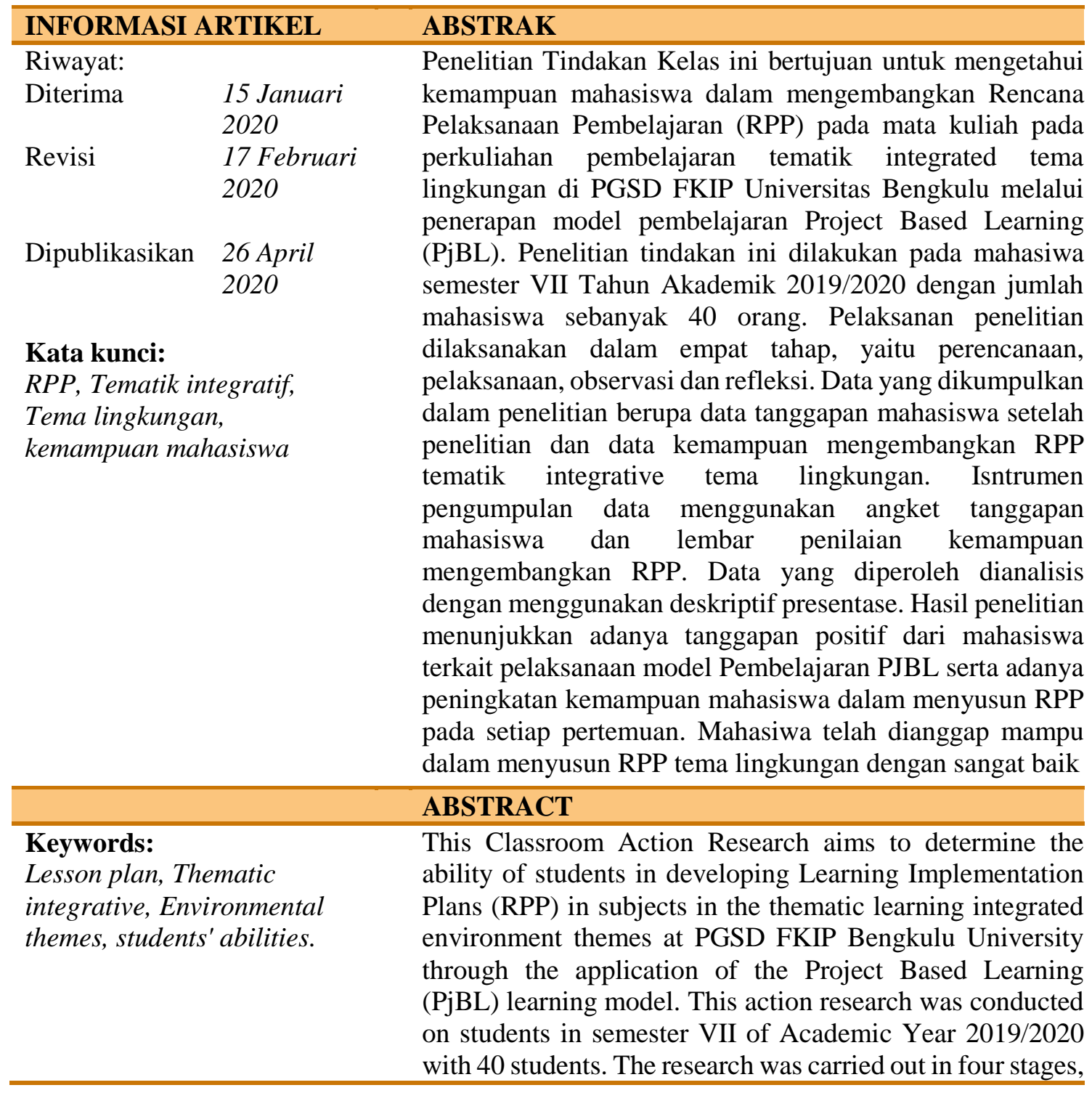

doi) $10.22219 / j p 2 s d$ 


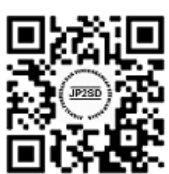

Copyright (c) 2020, Sri Dadi, Nani Yuliantini, Panut Setiono This is an open access article under the CC-BY-SA license

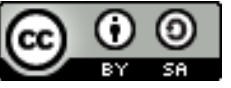

namely planning, implementation, observation, reflection. Data collected in the study were in the form of student response data after the study and data on the ability to develop integrative thematic RPPs on environmental themes. Data collection instruments used a student response questionnaire and an assessment sheet for the ability to develop lesson plans. The data obtained were analyzed using descriptive percentages. The results showed a positive response from students related to the implementation of the PPA Learning model and an increase in the ability of students to prepare lesson plans at each meeting. Students have been considered capable of compiling RPP environmental themes very well.

How to cite: Sri Dadi, Nani Yuliantini, Panut Setiono. (2020). Strategi Pengembangan RPP Melalui Model Pembelajaran Project Based Learning. Jurnal Pemikiran dan Pengembangan Sekolah Dasar, Vol 8 No 1, 10-18. doi: https://doi.org/ 10.22219/jp2sd.v8i1.10971

\section{PENDAHULUAN}

Sebagai calon guru sekolah dasar, mahasiwa Pendidikan Guru Sekolah Dasar (PGSD) harus memiliki kemampuan yang memadai sebagai guru professional di masa yang akan datang. Kemampuan ini harus terus dikembangkan seiring dengan perkembangan teknologi yang kian pesat (Husain, 2014; Jaedun, 2009; Mustari \& Rahman, 2014; Santoso, 2020). Setidaknya, untuk saat ini kemampuan merencanakan pembelajaran menjadi kunci keberhasilan dalam pelaksanaan pembelajaran yang akan dilaksanakan. Dengan perencanaan yang matang, pelaksanaan pembelajaran dapat berjalan optimal dan sesuai dengan tujuan pembelajaran yang diharapkan. Arifin (2013) menyatakan untuk menjadi guru yang berkemampuan tidaklah gampang, salah satunya ia harus memiliki kemampuan merencakana pembelajaran yang baik. Melalui kemampuan dan kemahiran dalam menyusun perencanaan pembelajaran yang akan disampaikan kepada siswa, akan tercapai tujuan pembelajaran secara optimal (Nurjaman, dkk., 2018).

Salah satu mata kuliah yang bertujuan mengembangkan kemampuan mahasiswa dalam membuat perencanaan pembelajaran (RPP) (Indriani, 2016; Izzati, 2017; Khusniati \& Pamelasari, 2014) adalah mata kuliah Pembelajaran Tematik Integratif tema Lingkungan. Pembelajaran pada mata kuliah ini berorientasi pada pengembangan kemampuan mahasiswa dalam menyusun RPP, mulai dari pemetaan subtema lingkungan, pemetaan kompetensi dasar yang sesuai dengan subtema, perumusan indikator pembelajaran, perumusan tujuan pembelajaran, pemilihan materi pembelajaran, pemilihan media pembelajaran, dan penyusunan rubrik penilaian yang sesuai dengan tujuan pembelajaran.

RPP merupakan salah satu komponen perangkat pembelajaran yang berisi rencana kegiatan pembelajaran (Cholily \& Suwandayani, 2019) sebagai pedoman dalam melaksanakan pembelajaran di kelas (Suwandayani, 2018, BSNP, 2006). Menurut Muslich (2008) RPP merupakan rancangan pembelajaran yang disusun dalam unit-unit program untuk digunakan guru dalam proses pembelajaran di kelas. RPP yang disusun harus memiliki keterterapan yang tinggi, agar target pembelajaran dapat tercapai secara optimal.

Kemampuan mahasiswa dalam menyusun RPP dapat dijadikan sebagai pedoman untuk menampilkan penampilan terbaik dalam menyajikan materi pembelajaran di depan 
siswa (Izzati, 2017). RPP bagi guru dan calon guru merupakan muara dari seluruh pengetahuan teori yang dipahami oleh calon guru, penguasaan keterampilan dasar mengajar, pengetahuan yang mendalam tentang siswa dan karakteristiknya serta mampu mengontrol situasi kelas (Setyawanto, dkk., 2012)

Salah satu upaya meningatkan kemampuan mahasiswa dalam menyusun RPP untuk pembelajaran tematik integrative tema lingkungan dengan menerapkan pembelajaran model pembelajaran Project Based Learning (PjBL). PjBL merupakan salah satu model pembelajaran yang memanfaatkan masalah sebagai awal serta mengintegrasikan pengetahuan yang diperoleh sebagai pengalaman dalam implementasi kehidupan nyata. Model PjBL menitikberatkan pada penggunaan projek sebagai inti pembelajaran (Furi, dkk., 2018).

PjBL digunakan untuk permasalahan yang komplek yang diperlukan untuk melakukan investigasi dan memahi tugas yang akan dikerjakan. Menurut Abdullah (2013) PjBL merupakan strategi yang digunakan oleh pendidik dengan melibatkan peserta didik (mahasiwa) dalam menyelesaikan masalah-masalah dalam masyarakat. Hasil penelitian terdahulu menyatakan bahwa model PjBl dapat meningkatkan hasil belajar siswa (Dadi, 2016; Rasyid, 2019).

Implementasi model PjBL ini dapat membantu siswa untuk aktif dalam pembelajaran. Penerapan model ini telah sesuai dengan tujuan mata kuliah yang menuntut mahasiswa terampul merancang RPP tematik integrative pada tema lingkungan. Pada pertemuan awal, mahasiswa diberikan pemahaman materi secara mendalam terkait dengan komponen RPP serta prosedur pengembangannya. Kemudian dalam beberapa waktu pertemuan, mahasiswa diminta untuk menganalisis kualitas RPP yang digunakan di kelas nyata (sekolah riil). Pertemuan berikutnya dilanjutkan analisis perbandingan RPP dari guru dengan kajian teori yang telah dipelajari sebelumnya, untuk menemukan kelebihan dan kelemahan di dalamnya. Setelah mahasiswa menemukan kelemahan RPP guru, mahasiswa melanjutkan tugas praktik untuk menyusun RPP untuk satu sub-tema pembelajaran. Setelah RPP dikembangkan, dilakukan penilaian kelayakan oleh dosen pengampu. RPP yang sudah bagus dan layak ditampilkan di depan kelas melalui praktik pembelajaran. Sedangkan RPP yang belum layak, mahasiswa diminta untuk menyempurnakan sesuai dengan saran-saran yang diberikan.

Kolaborasi aktivitas penyusunan perencanaan dan praktik pembelajaran secara peer teaching diharapkan agar mahasiswa dapat fokus melaksanakan kegiatan pembelajaran sesuai dengan perencanaan yang telah disusun sebelumnya. Dari kegiatan tersebut, diharapkan mahasiswa mampu dan terampil menyusun RPP untuk pembelajaran tematik integratif pada tema Lingkungan. Dari uraian pendahuluan yang disampaikan, tujuan dilakukan Penelitian Tindakan Kelas ini yaitu untuk mendeskripsikan kemampuan mahasiswa dalam mengembangkan RPP serta menguraikan tanggapan mahasiswa setelah pembelajaran dengan model PjBL.

\section{METODE}

Penelitian ini didesain menggunakan metode Penelitian Tindakan Kelas (PTK). Mulyasa (2013:10) menyebutkan bahwa PTK bertujuan untuk memperbaiki kualitas proses dan hasil belajar sekelompok peserta didik. Dalam pelaksanaannya, peneliti sebagai instrumen yang terlibat langsung dalam proses penelitian. PTK ini dilaksanakan sesuai dengan model Kemmis \& Mc. Tagart yang dilakukan dalam empat tahap setiap siklusnya, yaitu perencanaan, pelaksanaa, observasi dan refleksi. Penelitian ini dilaksanakan selama 4 siklus, siklus pertama penelitian difokuskan pada matrikulasi teori 
pengembangan RPP, siklus kedua dilaksanakan dengan kegiatan analisis kualitas RPP guru lapangan, siklus ketiga merancang RPP dan siklus empat digunakan untuk praktik pembelajaran (peer teaching).

Subjek dalam penelitian ini berjumlah 40 orang yang sedang duduk di semester 7 dan mengontrak mata kuliah Pembelajaran Tematik Integratif tema Lingkungan. Dari jumlah tersebut terdiri dari 34 orang mahasiswa perempuan dan 6 orang mahasiswa lakilaki. Pemilihan subjek penelitian ini didasari pada rendahnya kemampuan mahasiswa dalam mengingat komponen-komponen RPP dan prosedur pengembangannya.

Data yang dikumpulkan dalam penelitian ini berupa: (1) data penilaian yang berasal dari lembar penilaian kelayakan RPP yang dikembangkan mahasiswa, dan (2) data berupa tanggapan mahasiswa setelah pembelajaran dilakukan. Data pertama dikumpulkan dengan menggunakan pedoman penilaian dengan teknik observasi kelayakan RPP yang dikembangkan, sedangkan data kedua dikumpulkan dengan menggunakan angket tanggapan mahasiswa.

Data yang sudah dikumpulkan dianalisis menggunakan teknik analisis data kualitatif dan kuantitatif. Data kualitatif dikumpulkan selama proses perkuliahan berlangsung yang akan digunakan untuk mendukung tahap refleksi guna perbaikan pelaksanaan pembelajaran di siklus berikutnya, juga untuk melihat sejauhmana keberhasilan tindakan yang telah dilakukan sehingga peneliti menyimpulkan bahwa penelitian tindakan diakhiri. Sedangkan untuk analisis data kuantitatif digunakan untuk dijadikan dasar penilaian keberhasilan tindakan sesuai berdasarkan data yang dikumpulkan. Data kuantitatif yang telah dikumpulkan selanjutnya akan dianalisis dengan rumus:

$$
\text { Nilai }=\frac{\text { Jumlah Skor Perolehan }}{\text { Jumlah Skor Maksimal }} \times 100
$$

Hasil yang diperoleh kemudian dikonversi sesuai dengan pernyataan Tabel 1 di bawah ini.

Tabel 1. Kriteria kemampuan

\begin{tabular}{ccc}
\hline No. & $\begin{array}{c}\text { \% Keberhasilan } \\
\text { Tindakan }\end{array}$ & $\begin{array}{c}\text { Taraf } \\
\text { Keberhasilan }\end{array}$ \\
\hline 1 & $80-100$ & Baik sekali \\
2 & $60-79$ & Baik \\
3 & $40-59$ & Cukup \\
4 & $10-39$ & Kurang \\
5 & $0-9$ & Gagal \\
\hline
\end{tabular}

Mahasiswa dianggap mampu mengembangkan RPP jika mendapat nilai serendahrendahnya sebesar 60 dengan predikat baik. Sedangkan kriteria keberhasilan kelas setidaknya $75 \%$ siswa mendapat kriteria baik.

\section{HASIL DAN PEMBAHASAN}

Pada bagian ini akan dijelaskan proses Penelitian Tindakan Kelas untuk meningkatkan kemampuan siswa mengembangkan RPP. Kegiatan penelitian ini dilaksanakan sebanyak empat siklus, masing-masing siklus materi yang diajarkan yakni, siklus pertama penelitian difokuskan pada matrikulasi teori pengembangan RPP, siklus 
kedua dilaksanakan dengan kegiatan analisis kualitas RPP guru lapangan, siklus ketiga merancang RPP dan siklus empat digunakan untuk praktik pembelajaran (peer teaching).

Tahapan yang dilakukan pada setiap siklus meliputi tahap perencanaan, tahap pelaksanaan, tahap observasi dan tahap refleksi. Pada tahap perencanaan tindakan, kegiatan yang dilakukan antara lain: (1) observasi pengetahuan mahasiswa tentang konsep RPP; (2) menganalisis kompetensi yang akan dikuasai oleh mahasiswa; (3) membuat bahan ajar yang sesuai; dan (4) mengembangkan instrumen penelitian.

Pada tahap pelaksanaan dan observasi tindakan, kegiatan yang dilakukan adalah melaksanakan kegiatan pembelajaran sesuai dengan rencana kegiatan yang telah disusun sebelumnya. Metode pembelajaran yang digunakan dalam penelitian ini yaitu metode diskusi kelompok. Metode ini dipilih karena paling efektik untuk pengajaran kelompok kecil. Dalam mempelajari kemampuan mengembangkan RPP dibutuhkan keterampilan yang kompleks, seperti berpikir kritis, pemecahan masalah dan memberikan kometar pribadi (Fauziah, 2011; Rahman, 2018; Syahbana, 2012). Penerapan metode diskusi kelompok juga diharapkan mendorong mahasiswa untuk percaya diri dalam pembelajaran. Hasil penelitian Sari (2013) menunjukkan hasil belajar peserta didik setelah menerapkan metode diskusi kelompok ini.

Pelaksanaan pembelajaran model PjBL untuk meningkatkan kemampuan mengembangkan RPP pada perkuliahan Tematik integratif pada tema lingkungan ini setiap siklus dilaksanakan masing-masing sebanyak 3 kali pertemuan pada pelaksanan penelitian tindakan kelas. Penilaian keterterapan model PjBL dilaksanakan setiap kegiatan pembelajaran. Penilaian ini difokuskan pada aktvitas guru dalam melaksanakan kegiatan pembelajaran, kemampuan mengembangkan RPP dan sikap mahasiswa selama proses pembelajaran berlangsung.

Penilian aktivitas guru dalam melaksanakan kegiatan pembelajaran difokuskan pada indikator, yaitu: (1) dosen memberikan pertanyaan mendasar sesuai topik permasalahan kepada mahasiwa; (2) dosen membuat desain proyek yang harus diselesaikan oleh mahasiswa; (3) dosen memberikan jadwal kegiatan proyek; (4) dosen melakukan monitoring dan bimbingan kemajuan proyek yang dikerjakan; (5) melalukan uji proses dan hasil belajara; (6) melakukan evaluasi pembelajaran yang telah dilaksanakan. Hasil penghitungan keterlaksanaan pembelajaran dihitung dengan rumus:

$$
\text { K.B }=\frac{\text { Jumlah Skor Perolehan }}{\text { Jumlah Skor Maksimal }} \times 100 \%
$$

Teknik analisa data dilakukan secara deskriptif, dan disajikan dalam bentuk tabel. Berikut ini disajikan hasil penilaian aktivitas guru dalam melaksanakan Model pembelajaran PjBL selama kegiatan PTK berlangsung pada Tabel 2 di bawah ini.

Tabel 2. Hasil Penilaian Keterlaksanaan Pembelajaran

\begin{tabular}{lcccc}
\hline Keterangan & $\begin{array}{c}\text { Siklus } \\
\text { I }\end{array}$ & $\begin{array}{c}\text { Siklus } \\
\text { II }\end{array}$ & $\begin{array}{c}\text { Siklus } \\
\text { III }\end{array}$ & $\begin{array}{c}\text { Siklus } \\
\text { IV }\end{array}$ \\
\hline $\begin{array}{l}\text { Rata-rata } \\
\text { skor }\end{array}$ & $56 \%$ & $75 \%$ & $76,8 \%$ & $86,9 \%$ \\
\hline Kriteria & $\begin{array}{c}\text { cukup } \\
\text { baik }\end{array}$ & $\begin{array}{c}\text { Baik } \\
\text { Sekali }\end{array}$ & $\begin{array}{c}\text { Baik } \\
\text { Sekali }\end{array}$ & $\begin{array}{c}\text { Baik } \\
\text { Sekali }\end{array}$ \\
\hline
\end{tabular}

Berdasarkan data tabel 2 dapat diketahun bahwa aktivitas guru setiap siklus mengalami peningkatan yang baik. Jika pada siklus I hanya sebesar 56\% maka, pada siklus II aktivitas guru meningkat menjadi $75 \%$ dengan kriteria baik sekali. Pada siklus ketiga aktivitas guru meningkat hingga mencapai 76,7\%, dan siklus keempat memperoleh 
skor sebesar 86,9\% dengan kriteria baik sekali. Dengan demikian dapat dikatakan bahwa penerapan model PjBL berhasil dilaksanakan oleh dosen.

Keterlaksanaan model pembelajaran PjBL yang baik diharapkan mampu meningkatkan kemampuan mengembangkan RPP. Menurut Nugraha, dkk (2018) kegiatan pembelajaran belajar mengajar yang dilakukan di sekolah memiliki tujuan yaitu hasil belajar yang baik. Demikian juga Susanto (2013) menyatakan bahwa pencapaian hasil belajar siswa salah satunya disebabkan oleh model penyajian materi pembelajaran yang disediakan oleh guru dan suasan pembelajaran yang menyenangkan.

Penilaian kemampuan mahasiswa dalam mengembangkan RPP, komponen penilaian kemampuan ini meliputi: (1) kesesuaian komponen RPP dengan Standar Proses; (2) kesesuaian sub-tema pembelajaran dengan tema yang telah ditetapkan; (3) ketepatan merumuskan indikator pembelajaran dengan Kompetensi Dasar; (4) kesesuaian rumusan tujuan pembelajaran dengan indikator; (5) ketepatan merumuskan tingkat penguasaan kompetensi pada indikator dan tujuan pembelajaran dengan Kompetensi Dasar; (6) kejelasan kegiatan pembelajaran yang dilakukan mahasiswa dan dosen; (7) kesesuaian model pembelajaran, metode pembelajaran dengan tujuan pembelajaran; (8) kesesuaian penggunaan media/alat dengan metode pembelajaran dengan $\mathrm{KI} / \mathrm{KD}$; (9) penggunaan sumber belajar yang bervariasi selain dari buku pegangan; (10) pengalokasian waktu dengan materi dan skenario dalam RPP; (11) sasaran penilaian yang dituju serta jenis teknik penilaian/evaluasi yang digunakan. Hasil penghitungan keterlaksanaan pembelajaran dihitung dengan rumus:

\section{K.B = Jumlah Skor Perolehan $\times 100 \%$ \\ Jumlah Skor Maksimal}

Teknik analisa data dilakukan secara deskriptif, dan disajikan dalam bentuk tabel. Berikut ini disajikan hasil penilaian.

Tabel 3. Hasil Penilaian Kemampuan Mengembangkan RPP

\begin{tabular}{clcccc}
\hline \multirow{2}{*}{ No. } & \multicolumn{1}{c}{ Indikator Penilaian } & \multicolumn{4}{c}{ Hasil Siklus (\%) } \\
\cline { 3 - 6 } & \multicolumn{1}{c}{ I } & II & III & IV \\
\hline 1 & $\begin{array}{l}\text { Kesesuaian komponen RPP dengan } \\
\text { Standar Proses }\end{array}$ & 54 & 63,2 & 76 & 88,2 \\
\hline 2 & $\begin{array}{l}\text { Kesesuaian sub-tema pembelajaran dengan } \\
\text { tema yang telah ditetapkan }\end{array}$ & 62,2 & 71,4 & 84,2 & 96,4 \\
\hline 3 & $\begin{array}{l}\text { ketepatan merumuskan indikator } \\
\text { pembelajaran dengan Kompetensi Dasar }\end{array}$ & 52,4 & 61,6 & 74,4 & 86,6 \\
\hline 4 & $\begin{array}{l}\text { kesesuaian rumusan tujuan pembelajaran } \\
\text { dengan indikator }\end{array}$ & 52 & 61,2 & 74 & 86,2 \\
\hline 5 & $\begin{array}{l}\text { Ketepatan merumuskan tingkat } \\
\text { penguasaan kompetensi pada indikator dan } \\
\text { tujuan pembelajaran dengan Kompetensi }\end{array}$ & 54,6 & 63,8 & 76,6 & 88,8 \\
\hline $\begin{array}{l}\text { Dasar } \\
6\end{array}$ & $\begin{array}{l}\text { Kejelasan kegiatan pembelajaran yang } \\
\text { dilakukan mahasiswa dan dosen }\end{array}$ & 56,8 & 66 & 78,8 & 91 \\
\hline 7 & $\begin{array}{l}\text { Kesesuaian model pembelajaran, metode } \\
\text { pembelajaran dengan tujuan pembelajaran }\end{array}$ & 58,4 & 67,6 & 80,4 & 92,6 \\
\hline 8 & $\begin{array}{l}\text { Kesesuaian penggunaan media/alat dengan } \\
\text { metode pembelajaran dengan KI/KD }\end{array}$ & 56,8 & 66 & 78,8 & 91 \\
\hline 9 & $\begin{array}{l}\text { Penggunaan sumber belajar yang } \\
\text { bervariasi selain dari buku pegangan }\end{array}$ & 58,2 & 67,4 & 80,2 & 92,4 \\
\hline 10 & $\begin{array}{l}\text { Pengalokasian waktu dengan materi dan } \\
\text { skenario dalam RPP }\end{array}$ & 56,4 & 65,6 & 78,4 & 90,6 \\
\hline & & & &
\end{tabular}


16 JP2SD (Jurnal Pemikiran dan Pengembangan Sekolah Dasar), Vol. 8 , No 1, April 2020 hlm 10-18 http://ejournal.umm.ac.id/index.php/jp2sd

\begin{tabular}{|c|c|c|c|c|c|}
\hline \multirow{2}{*}{ No. } & \multirow{2}{*}{ Indikator Penilaian } & \multicolumn{4}{|c|}{ Hasil Siklus (\%) } \\
\hline & & I & II & III & IV \\
\hline 11 & $\begin{array}{l}\text { Sasaran penilaian yang dituju serta jenis } \\
\text { teknik penilaian/evaluasi yang digunakan }\end{array}$ & 56,2 & 65,4 & 78,2 & 90,4 \\
\hline & Rata-Rata & $\begin{array}{c}56,1 \\
8\end{array}$ & $\begin{array}{c}65,3 \\
8\end{array}$ & $\begin{array}{c}78,1 \\
8\end{array}$ & $\begin{array}{c}90,3 \\
8\end{array}$ \\
\hline
\end{tabular}

Teknik analisa data dilakukan secara deskriptif, Dari tabel 3. di atas dapat dilihat bahwa pada Siklus I skor perolehan kemampuan mengembangkan RPP sebesar 56,18\% dengan kriteria "Cukup baik". Pada siklus II skor yang diperoleh sebesar 65,38\% dengan kriteria "Baik". Pada siklus III skor perolehan sebesar 78,18\% dengan kriteria "Baik". Dan pada siklus IV diperoleh skor 90,38\% dengan kriteria "Baik Sekali".

Dari data tersebut dapat dikatakan bahwa penelitian tindakan kelas penerapan model pembelajaran PjBL dapat dikatakan berhasil untuk meningkatkan kemampuan mengembangkan RPP oleh mahasiswa Prodi PGSD pada perkuliahan Pembelajaran Tematik Integratif pada Tema Lingkungan.

Berdasarkan empat siklus tindakan pembelajaran tematik integrated tema lingkungan dengan menerapkan model pembelajaran Project Based Learning mampu memberikan peningkatan skor. RPP sangat penting dalam program pembelajaran. RPP merupakan rancangan program pembelajaran satu atau dua kelompok mata pelajaran yang berisi tentang standar kompetensi dan kompetensi dasar yang harus dicapai oleh siswa, pokok materi yang harus dipelajari siswa, pokok materi serta cara mempelajari dan mengetahui tercapainya kompetensi yang telah ditentukan(Pendidikan, 2007; Prastowo, 2017; Rusman, 2013)

Sebagai calon guru, mahasiswa harus mampu memahami kurikulum yang berlaku dengan baik. Menurut Mulyasa (2008:31) dikatakan bahwa seorang guru yang kurang memahami kurikulum dengan baik, dapat berakibat pada pencapaian pembelajaran yang kurang optimal terhadap pencapaian hasil belajar peserta didik, baik kognitif, afektif dan psikomotor. Untuk itu guru harus mampu membuat perencanaan pembelajaran yang baik (Oviana, 2018)

\section{SIMPULAN}

Dari penelitian tindakan kelas yang telah dilakukan, dapat disimpulkan bahwa ada peningkatan kemampuan mahasiswa dalam mengembangkan RPP dengan menggunakan Model pembelajaran Project Based Learning. Terbukti, dari data yang telah dijelaskan di atas, ada peningkatan kemampuan mahasiswa dari siklus I hingga siklus IV. Kedepan, peningkatan kemampuan ini dapat dilakukan dengan menggunakan berbagai model pembelajaran lainnya, juga perlu mengintegrasikan dengan pemanfaatan media pembelajaran berbasis teknologi informasi.

\section{REFERENSI}

Arifin, Z. (2013). Menjadi Guru Profesional (Isu dan Tantangan Masa Depan). Edutech, Tahun 12, Vol.1, No.3, Oktober 2013 (132-155) DOI: 10.17509/edutech.v13i1.3225 tersedia online: https://ejournal.upi.edu/index.php/edutech/article/view/3225 diunduh pada 10 Januari 2019

Cholily, Y. M., \& Suwandayani, B. I. (2019). IMPLEMENTASI PENDEKATAN SAINTIFIK DALAM MATERI OPERASI ARITMATIKA PADA CALON GURU SD. TAMAN CENDEKIA: Jurnal Pendidikan Ke-SD-An, 3(2), 350-356. 
Fauziah, Y. N. (2011). Analisis kemampuan guru dalam mengembangkan keterampilan berpikir kreatif siswa Sekolah Dasar kelas V pada pembelajaran Ilmu Pengetahuan Alam. Jurnal Edisi Khusus, 1(1), 98-106.

Furi, L.I. F, Handayani, S., Maharani, S. 2018. Eksperimen Model Pembelajaran Project Based Learning Dan Project Based Learning Terintegrasi STEM Untuk Meningkatkan

Hasil Belajar Dan Kreativitas Siswa Pada Kompetensi Dasar Teknologi Pengolahan

Susu. Jurnal Penelitian Pendidikan Vol. 35 Nomor 1 Tahun 2018, Hal 49-60.

Husain, C. (2014). Pemanfaatan teknologi informasi dan komunikasi dalam pembelajaran di SMA Muhammadiyah Tarakan. Jurnal Kebijakan Dan Pengembangan Pendidikan, 2(2).

Indriani, F. (2016). Kompetensi Pedagogik Mahasiswa Dalam Mengelola Pembelajaran Tematik Integratif Kurikulum 2013 Pada Pengajaran Micro di PGSD UAD Yogyakarta. ELEMENTARY SCHOOL (Jurnal Pendidikan Dan Pembelajaran $\mathrm{Ke}-\mathrm{SD}-\mathrm{An}, 3(1)$.

Izzati, N. (2017). Meningkatkan Kemampuan Mahasiswa dalam Menyusun RPP melalui Penerapan Model Pembelajaran Berbasis Portofolio (Studi Kuasi Eksperimen terhadap Mahasiswa Tadris Matematika IAIN Syekh Nurjati Cirebon). Euclid, 4(1).

Jaedun, A. (2009). Evaluasi kinerja profesional guru.Makalah.Jaedun@Yahoo.Com. Hall-16. Html.

Mulyasa. (2013). Praktik Penelitian Tindakan Kelas. Bandung: PT Remaja Rosdakarya

Mulyasa, E. (2008). Kurikulum Tingkat Satuan Pendidikan. Bandung: Remaja Rosdakarya

Mustari, M., \& Rahman, M. T. (2014). Manajemen pendidikan. RajaGrafika Persada.

Muslich, M. (2008) Kurikulum Tingkat Satuan Pendidikan: Dasar Pemahaman dan Pengembangan. Jakarta: Bumi Aksara

Nugraha, A.R., Kristin, F., Anugraheni, I. (2018). Penerapan Model Pembelajaran Project Based Learning (PjBL) Untuk Meningkatkan Kreativitas Dan Hasil Belajar IPA Pada Siswa Kelas 5 SD. KALAM CENDEKIA PGSD KEBUMEN. Edisi Vol 6, No 4.1 tahun 2018. Hal 9-15.

Nurjaman, A., Purwasih, R., Sari, I.P. (2018) Meningkatkan Kemampuan Mahasiswa Dalam Membuat RPP Melalui Penerapan Model Pembelajaran Project Based Learning. Jurnal Mercumatika : Jurnal Penelitian Matematika dan Pendidikan Matematika Vol. 2, No 2, April 2018, pp. 33-42 ISSN: 2548-1819.

Khusniati, M., \& Pamelasari, S. D. (2014). Penerapan Critical Review terhadap Buku Guru IPA Kurikulum 2013 untuk Mengembangkan Kemampuan Mahasiswa dalam Menyusun Perangkat Pembelajaran Berpendekatan Saintifik. Jurnal Pendidikan IPA Indonesia, 3(2).

Oviana, W. (2018). Pengembangan Rencana Pelaksanaan Pembelajaran Berbasis Pendekatan Saintifik Oleh Guru SD Dan MI Di Kota Sabang. Pionir Jurnal Pendidikan. Edisi Volume 7, Nomor 1. Hal 1-16

Pendidikan, B. S. N. (2007). Standar Proses untuk Satuan Pendidikan Dasar dan Menengah. Badan Standar Nasional Pendidikan.

Prastowo, A. (2017). Menyusun Rencana Pelaksanaan Pembelajaran (RPP) Tematik Terpadu: Implementasi Kurikulum 2018 Untuk SD/MI. Kencana. 
Rahman, A. A. (2018). Pengembangan Perangkat Pembelajaran Berbasis pendekatan Realistik untuk Meningkatkan Kemampuan Pemecahan Masalah Matematis Siswa SMP N 3 Langsa. MAJU: Jurnal Ilmiah Pendidikan Matematika, 4(1).

Rasyid, AHA. (2019) Penerapan Model Pembelajaran Project Based Learning Untuk Meningkatkan Hasil Belajar Mahasiswa. Journal of Vocational and Technical Education.

Sari, N. E. (2013) Penerapan Metode Diskusi Kelompok Dalam Pembelajaran Kontekstual Guna Meningkatkan Hasil Belajar IPS Ekonomi Siswa Kelas VII SMPN 2 Dolopo Madiun. Equilibrium: Jurnal Ilmiah Ekonomi dan Pembelajarannya. Vol 1, No 1 (2013). Hal 32-44

Setyawanto, A., Sunaryo, Basuki, I., (2012). Rencana Pelaksanaan Pembelajaran (Rpp) Guru Bahasaindonesiatingkat Smp Di Kotamalang. https://jurnalonline.um.ac.id/data/artikel/artikelB75014B49ADF96FF1A3C8AA02E089935.p $\underline{\mathrm{df}}$

Susanto, A. ( 2013). Teori Belajar dan Pembelajaran di Sekolah Dasar. Jakarta: Kencana Prenadamedia Group

Santoso, F. B. (2020). Pengembangan Kompetensi Guru di Era Revolusi Industri 4.0. Revitalisasi Manajemen Pendidikan Anak Usia Dini (PAUD) Di Era Revolusi Industri, 4.

Suwandayani, B. I. (2018). Analisis Perencanaan Pembelajaran Tematik Pada Kurikulum 2013 di SD Negeri Kauman I Malang. ELSE (Elementary School Education Journal): Jurnal Pendidikan Dan Pembelajaran Sekolah Dasar, 2(1), $78-88$.

Syahbana, A. (2012). Pengembangan perangkat pembelajaran berbasis kontekstual untuk mengukur kemampuan berpikir kritis matematis siswa SMP. Edumatica: Jurnal Pendidikan Matematika, 2(02). 